\title{
APPLICATION OF LACTOBACILLUS CASEI 01 AND OLIGOFRUCTOSE-ENRICHED INULIN IN AYRAN
}

\author{
Tanja Petreska Ivanovska ${ }^{1 *}$, Zoran Zhivikj ${ }^{1}$, Liljana Bogdanovska ${ }^{2}$, Kristina Mladenovska ${ }^{3}$, \\ Lidija Petrushevska-Tozi ${ }^{1}$
}

${ }^{1}$ Institute of Applied Biochemistry, Faculty of Pharmacy, Ss. Cyril and Methodius University, Mother Theresa 47, 1000 Skopje, Republic of Macedonia

${ }^{2}$ Institute of Applied Chemistry and Pharmaceutical Analyses, Faculty of Pharmacy, Ss. Cyril and Methodius University, Mother Theresa 47, 1000 Skopje, Republic of Macedonia

${ }^{3}$ Institute of Pharmaceutical Technology, Faculty of Pharmacy,

Ss. Cyril and Methodius University, Mother Theresa 47, 1000 Skopje, Republic of Macedonia

tpetreska@ff.ukim.edu.mk

This study aimed to develop a probiotic/synbiotic ayran with a sufficient number of live bacteria Lactobacillus casei 01 (L. casei 01) during the product shelf-life. Under conditions of refrigerated storage for 15 days, probiotic survival and organic acid (lactic, acetic, propionic and butyric acid) production were evaluated. Simultaneously, $\mathrm{pH}$, titratable acidity, total solids, and carbohydrate, protein, fat and mineral contents of the samples were examined. Overall results of the chemical analyses indicated the quality of the prepared samples to be comparable with the conventional ayran used as a matrix for probiotic/synbiotic supplementation. L. casei 01 survived better in ayran containing synbiotic chitosan-Caalginate microparticles compared to samples enriched with non-encapsulated probiotic alone or with synbiotic ( $L$. casei 01 + oligofructose-enriched inulin), followed by increased production of lactic, acetic and propionic acid. Probiotic/synbiotic ayran may contribute to a healthy diet for consumers, while the sample enriched with microencapsulated formulation is advantageous in terms of probiotic activity.

Keywords: probiotic ayran; synbiotic ayran; synbiotic microparticles; Lactobacillus casei 01; oligofructose-enriched inulin

\section{ПОДГОТОВКА НА ФУНКЦИОНАЛЕН АЈРАН СО LACTOBACILLUS CASEI 01 И ИНУЛИН ЗБОГАТЕН СО ОЛИГОФРУКТОЗА}

Цел на ова истражување беше подготовка на пробиотски/синбиотски ајран кој во периодот на употреба на производот ќе содржи терапевтско ниво на витални клетки на пробиотикот Lactobacillus casei 01 (L. casei 01). Во текот на 15 дена чување на примероците во фрижидер беа анализирани виталноста на пробиотикот и продукцијата на органски киселини со кратки низи (млечна, оцетна, пропионска и бутерна киселина). Паралелно со овие анализи во примероците беа определени следниве параметри: $\mathrm{pH}$, титрациски ацидитет, суви материи, како и содржината на протеини, масти, јаглехидрати и минерали. Севкупната хемиска анализа покажа дека квалитетот на подготвените примероци соодветствува со квалитетот на конвенционалниот ајран применет како матрикс за пробиотско односно синбиотско збогатување. Ајранот подготвен со синбиотските цитозан-Са-алгинатни микрочестички се карактеризира со најдобри функционални својства, поголема виталност на пробиотикот и продукција на органски киселини во споредба со примероците збогатени со неинкапсулиран пробиотик или синбиотик (L. casei $01+$ инулин збогатен со олигофруктоза) и затоа може да биде дел од здравата исхрана на потрошувачите.

Клучни зборови: пробиотски ајран; синбиотски ајран; синбиотски микрочестички; Lactobacillus casei 01; инулин збогатен со олигофруктоза 


\section{INTRODUCTION}

Fermented dairy products, probiotics and prebiotics have gained increased interest recently. They act as supports to host physiology by regulating the gut microbiota composition and stability. Implementation of nutritional concepts for modulating gut microbiota dysbiosis by administration of probiotic enriched food may contribute to health improvement as well as to reductions in allergic disease symptoms, metabolic syndrome related diseases and gastro-enterological diseases [1]. Consumption of probiotic milks provides health benefits well beyond the starting products [2]. In this respect, good ACE-inhibitory activity and antioxidant properties in vitro were reported for the strain Lactobacillus casei 01 combined with inulin in sheep milk ice cream [3]. Administration of ayran containing 8.5-8.9 $\log$ CFU g ${ }^{-1}$ L. casei 01 and $1.5 \%$ oligofructose-enriched inulin was found to alleviate colonic inflammation and to increase fecal lactobacilli counts in the trinitrobenzenesulfonic (TNBS) acid model of rat colitis [4]. In a randomized, double-blind, placebocontrolled study, L. casei 01 , provided to women with rheumatoid arthritis at a dosage of $10^{8} \mathrm{CFU}$ per capsule daily for a period of 8 weeks, significantly decreased the disease activity score and improved the inflammatory status of patients by regulating the proportion between pro- and antiinflammatory cytokines [5]. In general, probiotic products should contain at least $10^{6}-10^{7}$ live microorganisms per $\mathrm{g}$ or $\mathrm{ml}$ at the expiry date to exert their therapeutic effects [6]. Hence, the most important aspect of a probiotic is to remain viable during processing and storage of the food product, and after administration to survive and multiply in the host and to provide its health benefits. Development of probiotic dairy products implies different technological operations, such as adding of antioxidants or glucose oxidase to minimize the exposure of the cells to oxygen and to increase their stability [7]. Viability loss, which is caused by light, pressure and high temperatures and the presence of oxygen, moisture and salts, may be significantly reduced by immobilization or microencapsulation of the probiotic bacteria in a polymer matrix [8]. Microencapsulation is an advantageous approach used to improve probiotic viability, allowing diffusion of molecules essential for cell metabolism, such as nutrients, oxygen and growth factors into the matrix [8], thereby supporting the viability of the cells and the outward diffusion of waste products. In addition, microencapsulation could also enable controlled and targeted release, by depositing the entrapped cells across the small and large intestine [9]. Among commonly used microencapsulation techniques, such as extrusion, emulsion and spray-drying, the last technique is often applied due to its low cost, the ability to process large volumes of solutions on a continuous basis, and the manufacture of smaller particles with more homogenous size distribution [10], suitable to be used in the food industry.

Ayran is traditional Turkish non-alcoholic fermented dairy drink. It can be prepared at home by addition of water to yogurt, or industrially produced with addition of Streptococcus thermophilus and L. delbrueckii subsp. bulgaricus to standardized milk for fermentation [11]. According to the Turkish Food Codex [11], ayran is a fresh product with a limited shelf-life (10-15 days) that contains at least $2.8 \mathrm{~g}$ protein, $6 \mathrm{~g}$ fat-free solids per $100 \mathrm{ml}$, and fat no lower than $1.8,0.8$ and $0.15 \mathrm{~g}$ for full fat, semi-skimmed and skimmed product, respectively. Ayran as a fermented product is easily digestible and it is considered valuable due to the high content of vitamins and calcium [12]. Enrichment of ayran with health-promoting compounds such as probiotics and/or prebiotics may further increase the functional value of the product. In addition, probiotic ayran can easily be accepted by the consumers due to the inherent connection of lactic acid bacteria to dairy products. Prebiotics are compounds reported to have positive effects on the viability of probiotics applied in food products and on the physicochemical attributes of the products $[3,13]$. 'Synbiotic' refers to a synergism between probiotics and prebiotics. Adding of hydrocolloid prebiotics such as inulin [14] may improve the consistency by reducing the syneresis (serum separation) which is a common occurrence during storage of ayran [15]. In general, a functional food product design considers several aspects, such as functional properties of the product, sensory appeal, shelf-life, physicochemical stability, health claim approval and safety evaluation [16]. Considering these, development of a probiotic- or synbiotic enriched food with favorable physicochemical and sensory attributes is a challenge from the scientific and industrial standpoint.

The aim of this study was to prepare a new probiotic or synbiotic ayran with a sufficient number of live bacteria $L$. casei 01 and healthpromoting effects, while maintaining or enhancing the quality of the conventional ayran. Herein, three samples containing (i) non-encapsulated $L$. casei 01, (ii) non-encapsulated combination of $L$. casei 01 and oligofructose-enriched inulin (Synergy 1) and (iii) L. casei 01 and Synergy 1 loaded chi- 
tosan-Ca-alginate microparticles were prepared. Synbiotic chitosan-Ca-alginate microparticles used in this study were developed and optimized in our previous work [17].

\section{EXPERIMENTAL}

\subsection{Material}

Freeze-dried probiotic culture of Lactobacillus paracasei subsp. paracasei (Lactobacillus casei 01) was provided from Chr. Hansen, Hoersholm, Denmark. Commercially available ayran (Zdravje Radovo, Macedonia) was used for probiotic/synbiotic sample preparation. Synergy 1, a mixture of oligofructose (DP 2-8) and long-chain inulin fraction (DP 10-60) (Orafti-Rue L. Maréchal, Tienen, Belgium) was applied as prebiotic. Sodium alginate (Protanal LF 10/60 LS, fG 35-45\%) (IMCD, FMC BioPolymer, Ayrshire, UK) and chitosan with deacetylation degree $\geq 85 \%$ and low viscosity 342 (viscosity of $10 \mathrm{mg} \mathrm{g}^{-1}$ solution in acetic acid $20-100 \mathrm{mPa} s, \mathrm{M}_{\mathrm{w}} 150 \mathrm{kDa}$ ) (France Chitine, Marseille, France) were used as encapsulating agents. The cross-linking agent $\mathrm{CaCl}_{2}$, MRS broth, MRS agar and peptone water were supplied by Merck, KGaA, Darmstadt, Germany. All reagents were of analytical grade.

\subsection{Preparation of synbiotic chitosan-Ca-alginate microparticles}

Synbiotic chitosan-Ca-alginate microparticles were prepared according to the method described by Petreska Ivanovska et al. [17]; namely, an overnight-inoculated probiotic in MRS broth at $37^{\circ} \mathrm{C}$ to a cell load ca. $12 \log \mathrm{CFU} \mathrm{ml}{ }^{-1}$ was added to a mixture containing alginate $\left(40 \mathrm{mg} \mathrm{g}^{-1}\right)$ and prebiotic $\left(15 \mathrm{mg} \mathrm{g}^{-1}\right)$. Then, on the same day, the synbiotic alginate suspension was spray-dried (Büchi Mini Spray Dryer B-290, Switzerland) at inlet temperature $120^{\circ} \mathrm{C}$, outlet temperature $58 \pm 3$

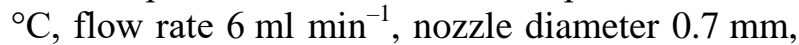
aspirator pressure $90 \%$ and atomizer pressure 600 $\mathrm{Nl} \mathrm{h}{ }^{-1}$. Dried powder samples were slowly added to a $50 \mathrm{mg} \mathrm{g}^{-1} \mathrm{CaCl}_{2}$ and $5 \mathrm{mg} \mathrm{g}^{-1}$ chitosan dissolved in $1 \% \mathrm{v} / \mathrm{v}$ acetic acid, under continuous stirring. The microparticles were allowed to stir on a magnetic stirrer for at least $3 \mathrm{~h}$ at $25^{\circ} \mathrm{C}$. Then, the particles were separated by centrifugation at 1500 $\times g$ for $10 \mathrm{~min}$, rinsed with sterile saline solution and then freeze-dried at 0.070 mbar and $-50{ }^{\circ} \mathrm{C}$ for $24 \mathrm{~h}$ (FreeZone Freeze Dry System, Labconco, Kansas City, USA). Experimental design using a polynomial regression model at the $2^{\text {nd }}$ level was applied to optimize the microparticulate formulation considering physicochemical (particle size, zeta-potential, Ca-content) and functional properties (viability of the probiotic during microencapsulation and in simulated gastrointestinal conditions). The entrapment efficiency of the microparticles of optimal formulation was $89.5 \pm 1.2 \%$. Cationic microparticles were prepared (zeta-potential, $+19.04 \pm 0.3 \mathrm{mV}$ ), with a spherical, but also flattened disk shape, narrow size distribution $\left(\mathrm{d}_{50}\right.$ $8.6 \pm 0.3 \mu \mathrm{m})$ and $11.3 \pm 0.13 \log \mathrm{CFU} \mathrm{g}{ }^{-1}$ viable cells of L. casei 01 after freeze-drying [17].

\subsection{Preparation of probiotic/synbiotic ayran samples}

Commercial ayran was used to prepare three samples enriched with: (i) the probiotic $L$. casei 01 alone, (ii) L. casei 01 in combination with Synergy 1 and (iii) synbiotic (L. casei $01+$ Synergy 1) loaded chitosan-Ca-alginate microparticles. All the samples were placed into sterile Erlenmeyer flasks and inoculated with an equivalent cell count of the probiotic strain (approximately $9.5 \log \mathrm{CFU}$ $\mathrm{ml}^{-1}$ ) and prebiotic $\left(15 \mathrm{mg} \mathrm{g}^{-1}\right)$ in nonencapsulated or encapsulated form. Ayran samples enriched with probiotic and synbiotic and a sample of the commercial ayran used as a control sample were stored in a refrigerator at $4{ }^{\circ} \mathrm{C}$ for 15 days. Qualitative and quantitative analyses of prepared ayran samples were performed at predetermined time intervals during the shelf-life of the commercial ayran.

\subsection{Chemical analyses}

The $\mathrm{pH}$ measurements (PB-11 Sartorius, Goettingen, Germany) of ayran samples were done simultaneously with the viability assays at day 1,3 , $5,7,10$ and 15 during the shelf-life of the product ayran.

Titratable acidity was determined by acidbase titration using $0.1 \mathrm{~mol}^{-1} \mathrm{NaOH}$ with phenolphthalein (ACS Reagent, Merck, KGaA, Darmstadt, Germany) as indicator [18]. To calculate the acidity of the samples, Eq. (1) was used:

Titratable acidity $(\%)=\frac{0.0090 \times V(\mathrm{NaOH})}{\text { weight of the sample }} \times 100$,

where $V$ is the volume of $\mathrm{NaOH}$ used for neutralization of the acidity.

Total solids were determined gravimetrically. Briefly, $5 \mathrm{~g}$ of each sample was transferred into a pre-weighed round flat-bottomed porcelain dish provided with a fitting lid. The dish, with the sam- 
ple and lid, was heated at $103 \pm 2{ }^{\circ} \mathrm{C}$, cooled in a desiccator and weighed until the difference between the two successive weightings did not exceed $1 \mathrm{mg}$. The results were expressed as grams of total solids per $100 \mathrm{~g}$ of sample.

Fats were quantified using graduated glass butyrometers for direct measurement of fat in dairy products according to the Gerber method [19]. Sulfuric acid (RD 1.820-1.825) was used to separate fat from proteins in the butyrometer. In order to facilitate the separation of fat on the surface of the samples, amyl alcohol (Alkaloid, Skopje, Macedonia) was used.

Protein concentration was measured based on the method described by Bradford [20], using the Coomassie protein assay reagent and bovine serum albumin as a standard. Prior to protein quantification, the $\mathrm{pH}$ of ayran samples was adjusted to 3.8 using $50 \%$ solution of lactic acid (SigmaAldrich, St. Louis, USA). Then, the samples were centrifuged $(7200 \mathrm{rpm} ; 10 \mathrm{~min})$ and the $\mathrm{pH}$ of the collected supernatants was readjusted to 7.0. Afterwards, the samples were recentrifuged at $7200 \mathrm{rpm}$ for $10 \mathrm{~min}$ [21], and the protein concentration in the obtained supernatants was measured at $595 \mathrm{~nm}$ (Perkin Elmer UV/VIS Spectrometer, Lambda 16, Arizona, USA).

Quantitative analysis of total carbohydrates was carried out using the phenol sulfuric acid method. In hot acidic medium, glucose is dehydrated to hydroxymethyl furfural which reacts with phenol to produce a yellow-brown colored product. The samples were first hydrolyzed with $2.5 \mathrm{~mol} \mathrm{l}^{-1}$ $\mathrm{HCl}$, in a boiling water bath for $3 \mathrm{~h}$. Cooled samples were neutralized with solid sodium carbonate and centrifuged [22]. Afterwards, to a set of solutions with known glucose concentrations of 0.2 , $0.4,0.6,0.8$, and $1 \mathrm{mg}$ per $1 \mathrm{ml}$, as well as the sample solutions adjusted to a total volume of 0.2 $\mathrm{ml}$ with distilled water, $0.2 \mathrm{ml}$ of phenol and $1 \mathrm{ml}$ of $96 \%$ sulfuric acid were added. The solutions were mixed for $10 \mathrm{~min}$, placed in a water bath at $25-30{ }^{\circ} \mathrm{C}$ for $20 \mathrm{~min}$ and the absorbance measured at $490 \mathrm{~nm}$ (Perkin Elmer UV/VIS Spectrometer, Lambda 16, Arizona, USA).

Atomic absorption spectrometry was used to quantify $\mathrm{Na}, \mathrm{K}$ and $\mathrm{Ca}$ in the ayran samples. Prior to analysis, samples were digested with concentrated nitric acid $\left(25 \mathrm{mg} \mathrm{ml}^{-1}\right)$ in a water bath heated at $60-70{ }^{\circ} \mathrm{C}$.

\subsection{Microbiological analysis}

Viability of L. casei 01 was determined using a plate-count method after mixing of $1 \mathrm{ml}$ of the sample with $9 \mathrm{ml}$ of peptone water and then serially diluted. MRS agar supplemented with vancomycin $\left(1 \mu \mathrm{g} \mathrm{ml}^{-1}\right)$ (Sigma-Aldrich, St. Louis, USA) was used for enumeration of $L$. casei 01 after 3 days of anaerobic incubation at $37{ }^{\circ} \mathrm{C}$. Vancomycin-sensitive $L$. bulgaricus and $S$. thermophilus used as starters in ayran fermentation were grown on MRS agar acidified to 5.4 [23]. For samples containing synbiotic microparticles, bacterial enumeration was performed, conducting the same procedure after releasing the entrapped cells from the microparticles [24]; namely, $1 \mathrm{~g}$ of the microparticles was re-suspended in $9 \mathrm{ml}$ of phosphate buffer $\left(0.1 \mathrm{~mol} \mathrm{l}^{-1}, \mathrm{pH} 7\right)$ and homogenized on a magnetic stirrer for $10 \mathrm{~min}$. Enumeration of viable cells was performed in triplicate and the average of the results expressed as CFU per $\mathrm{ml}$ of sample. The obtained results calculated in $\mathrm{CFU} \mathrm{ml}^{-}$ ${ }^{1}$ were converted to $\log \mathrm{CFU} \mathrm{ml}{ }^{-1}$.

\subsection{Determination of organic acid concentration}

The concentration of lactic acid and short chain fatty acids (SCFAs) in ayran samples was determined using an HPLC system (Agilent Technologies 1200, Palo Alto, USA) and ultraviolet detection at $210 \mathrm{~nm}$. The methods described by Wang et al. [25] and Zhao et al. [26] were used to quantify lactic and acetic acid, and propionic and butyric acid, respectively. For acid extraction, $2 \mathrm{ml}$ of $0.5 \mathrm{~mol} \mathrm{l}^{-1} \mathrm{H}_{2} \mathrm{SO}_{4}$ were added to a $2 \mathrm{ml}$ aliquot of the sample, thoroughly mixed for $30 \mathrm{~s}$ and centrifuged (12 $000 \mathrm{rpm} ; 15 \mathrm{~min}$ ). Supernatants were filtered through $0.45 \mu \mathrm{m}$ membrane (Minisart RC 25, Sartorius Stedim Biotech, GmbH, Goettingen, Germany). To analyze lactic and acetic acid, samples were loaded onto a thermostatically controlled reverse phase column $(250 \mathrm{~mm} \times 4.6 \mathrm{~mm}, 5 \mu \mathrm{m}$, Discovery HS C 18, Supelco Park, Bellefonte, PA, USA) set at $40{ }^{\circ} \mathrm{C}$ and eluted with $0.005 \mathrm{~mol} \mathrm{l}^{-1}$

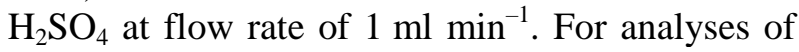
propionic and butyric acid, a mixture of phosphate buffer solution (15 mmol $\mathrm{l}^{-1}, \mathrm{pH}$ 2.1)-methanol $(85: 15, \mathrm{v} / \mathrm{v})$ was used at a rate of $1.5 \mathrm{ml} \mathrm{min}^{-1}$. Concentrations of lactic, acetic, propionic and butyric acids in the samples were calculated using the standard curves plotted for each acid.

\subsection{Statistical analysis}

Statistical analysis was carried out using twoway ANOVA followed by GraphPad Software Prism post-test to identify significant differences between means. Mean values and the standard deviation were calculated from triplicate experiments. 


\section{RESULTS AND DISCUSSION}

\subsection{Chemical properties of ayran samples}

Respective changes of chemical parameters examined in ayran samples $(\mathrm{pH}$, titratable acidity, total solids, and carbohydrate, protein, fat and mineral contents) during the storage period corresponding to the shelf-life of the conventional product are given in Table 1 .
The significant increase in acidification during refrigerated storage of yogurts, known as post-acidification, is likely to reduce the probiotic viability. However, the reduction in $\mathrm{pH}$ values was insignificant in all samples during 15 days of cold storage, as well as the difference in $\mathrm{pH}$ changes among the samples $(p>0.05)$, showing no excess of acidity when probiotic was added. In the same way, the titratable acidity was in an increasing trend, as expected, for these two parameters are inversely related to each other [13].

Table 1

Chemical properties of ayran samples

\begin{tabular}{|c|c|c|c|c|c|}
\hline \multirow[b]{2}{*}{ Parameters } & \multirow[b]{2}{*}{ Days } & \multicolumn{4}{|c|}{ Samples } \\
\hline & & $\begin{array}{l}\text { Control } \\
\text { ayran }\end{array}$ & $\begin{array}{l}\text { L. case } i \text {-enriched } \\
\text { ayran }\end{array}$ & $\begin{array}{l}\text { L. casei+Synergy } \\
1 \text {-enriched ayran }\end{array}$ & $\begin{array}{l}\text { Encapsulated } L \text {. } \\
\text { casei+Synergy } 1- \\
\text { enriched ayran }\end{array}$ \\
\hline \multirow{2}{*}{$\mathrm{pH}$} & 1 & $4.6 \pm 0.02$ & $4.5 \pm 0.02$ & $4.5 \pm 0.02$ & $4.6 \pm 0.03$ \\
\hline & 15 & $4.5 \pm 0.02$ & $4.4 \pm 0.03$ & $4.4 \pm 0.02$ & $4.5 \pm 0.03$ \\
\hline \multirow{2}{*}{ TA (\% 1.a.) } & 1 & $0.6 \pm 0.03$ & $0.7 \pm 0.05$ & $0.7 \pm 0.04$ & $0.7 \pm 0.03$ \\
\hline & 15 & $0.7 \pm 0.02$ & $0.8 \pm 0.05$ & $0.8 \pm 0.05$ & $0.7 \pm 0.02$ \\
\hline \multirow{2}{*}{ TS (\%) } & 1 & $8.0 \pm 0.18$ & $7.9 \pm 0.36$ & $9.2 \pm 0.55$ & $9.2 \pm 0.50$ \\
\hline & 15 & $8.4 \pm 0.15$ & $8.8 \pm 0.40$ & $10.4 \pm 0.50$ & $10.4 \pm 0.60$ \\
\hline \multirow{2}{*}{ Fats $(\%)$} & 1 & $1.0 \pm 0.00$ & $1.0 \pm 0.00$ & $1.0 \pm 0.00$ & $1.0 \pm 0.00$ \\
\hline & 15 & $1.0 \pm 0.00$ & $1.0 \pm 0.00$ & $1.0 \pm 0.00$ & $1.0 \pm 0.00$ \\
\hline \multirow{2}{*}{ Proteins $(\%)$} & 1 & $2.8 \pm 0.10$ & $2.8 \pm 0.07$ & $2.9 \pm 0.03$ & $2.8 \pm 0.08$ \\
\hline & 15 & $3.0 \pm 0.10$ & $2.9 \pm 0.06$ & $2.9 \pm 0.03$ & $2.9 \pm 0.07$ \\
\hline \multirow{2}{*}{ Carbohydrates (\%) } & 1 & $2.9 \pm 0.01$ & $2.6 \pm 0.03$ & $3.3 \pm 0.08$ & $3.1 \pm 0.10$ \\
\hline & 15 & $3.0 \pm 0.01$ & $2.7 \pm 0.05$ & $3.5 \pm 0.08$ & $3.3 \pm 0.12$ \\
\hline \multirow{2}{*}{$\mathrm{Na}\left(\mathrm{g} 100 \mathrm{ml}^{-1}\right)$} & 1 & $0.4 \pm 0.04$ & $0.4 \pm 0.05$ & $0.4 \pm 0.04$ & $0.4 \pm 0.04$ \\
\hline & 15 & $0.4 \pm 0.04$ & $0.4 \pm 0.04$ & $0.4 \pm 0.04$ & $0.4 \pm 0.05$ \\
\hline \multirow{2}{*}{$\mathrm{K}\left(\mathrm{mg} 100 \mathrm{ml}^{-1}\right)$} & 1 & $9.9 \pm 1.04$ & $13.4 \pm 1.25$ & $10.8 \pm 1.10$ & $11.5 \pm 1.20$ \\
\hline & 15 & $9.0 \pm 0.83$ & $8.7 \pm 0.62$ & $7.8 \pm 0.63$ & $9.2 \pm 0.80$ \\
\hline \multirow{2}{*}{$\mathrm{Ca}\left(\mathrm{mg} 100 \mathrm{ml}^{-1}\right)$} & 1 & $10.0 \pm 0.63$ & $9.3 \pm 0.83$ & $9.1 \pm 0.80$ & $22.0 \pm 1.88$ \\
\hline & 15 & $8.5 \pm 0.75$ & $7.5 \pm 0.63$ & $8.0 \pm 0.75$ & $27.0 \pm 0.00$ \\
\hline
\end{tabular}

Values are represented as mean \pm standard deviation $(n=3)$. The data were subjected to two-way ANOVA and the significance of the difference between means was determined using GraphPad Software Prism post-test. Significant differences $(p<0.05)$ between the samples and after 15 days of cold storage were not detected. TA: titratable acidity; TS: total solids; 1.a.: lactic acid.

In addition, titratable acidity in all examined samples was within the range of $0.64-0.77 \%$ of lactic acid, which is in accordance with the regulation given in the Turkish Food Codex [11] for titratable acidity of the product ayran.

Insignificant difference in total solids was found among ayran samples, but higher values were obtained for prebiotic-supplemented samples compared to control and/or samples containing probiotic only. Increase in total solids due to added inulin or oligofructose improved viscosity and firmness of fermented milks [14, 27]. Syneresis in ayran often increases to $30 \%$ [12]; hence, oligofructose-enriched inulin could have had an effect in the reduction of syneresis. These experiments were left for further research.

Probiotic bacteria possess proteolytic systems capable of releasing bioactive peptides, a process that takes place in particular during milk fermentation [28]. These activities may influence the amount of protein during storage of fermented products. However, the amount of protein varied insignificantly among the samples, probably depending on the amount of additive added to the ayran samples (Table 1); namely, the protein content in all examined samples was within the range documented for the product ayran (1.44-3.48\%) [29]. 
Certain Lactobacillus casei strains have been demonstrated to be able to remove the cholesterol from the media and to incorporate it into the cellular membrane [28], which may cause changes in fat content. The amount of fats in all ayran samples was $1 \%$, both before and after storage (Table 1). These values are in agreement with the fat content declared for the conventional product, satisfying the criterion given in the Turkish Food Codex [11] of no less than $0.8 \mathrm{~g}$ fat per $100 \mathrm{ml}$ for half-fat ayran.

Commercial ayran contains 3.0\% carbohydrate. Lower carbohydrate content in the sample containing non-encapsulated L. casei 01 (2.6$2.7 \%)$ compared to the control sample $(3.0 \%)$ could be due to the ability of probiotic cells to use the carbohydrates as nutrients for their survival. Carbohydrate content higher than $3.0 \%$ was found in ayran samples containing non-encapsulated (3.3 to $3.5 \%$ ) and encapsulated (3.1 to $3.3 \%$ ) synbiotic, as a result of the carbohydrate structure of the prebiotic. Slower release of the encapsulated prebiotic into the medium is probably the reason for the lower carbohydrate content found in the sample containing encapsulated synbiotic compared to that containing non-encapsulated synbiotic.

The lyophilized powder of $L$. casei 01 was found to contain sodium, potassium and calcium in our preliminary investigations of the probiotic cells. The sodium measurements evaluated both the possible effect of metabolic activities of $L$. casei 01 on the product, and the influence of added microparticles that were previously prepared using sodium alginate, chitosan and calcium chloride on the sodium level in ayran. Additionally, the measurements for calcium were conducted to investigate the influence of chitosan-Ca-alginate microparticles on the calcium content of the product itself. In the case of liberation of sodium ions into the medium, increased sodium may stimulate the separation of the serum in ayran and reduce the system stability. An increased amount of sodium was reported to be a stimulator of syneresis [15]. However, sodium content in all samples measured during storage complied with the declared salt content in the conventional product of $0.4 \%$, indicating good stability of the functional ayran samples. Results have shown a decreasing trend of potassium and calcium concentrations that followed the reduction of these parameters observed in control ayran during storage (Table 1). The decreased amount of potassium and calcium during the storage period compared to control ayran is probably due to interactions between added compounds and the medium. The exception was the increased calcium content during storage of the sample containing chitosan-Ca-alginate microparticles as a result of continuous calcium release from the microparticulate system.

\subsection{Survival of L. casei 01 in ayran}

In order to evaluate the ability of free and encapsulated $L$. casei 01 to survive in ayran during the shelf-life of the product, storage stability assays were performed at $4{ }^{\circ} \mathrm{C}$. Results are shown in Figure 1.

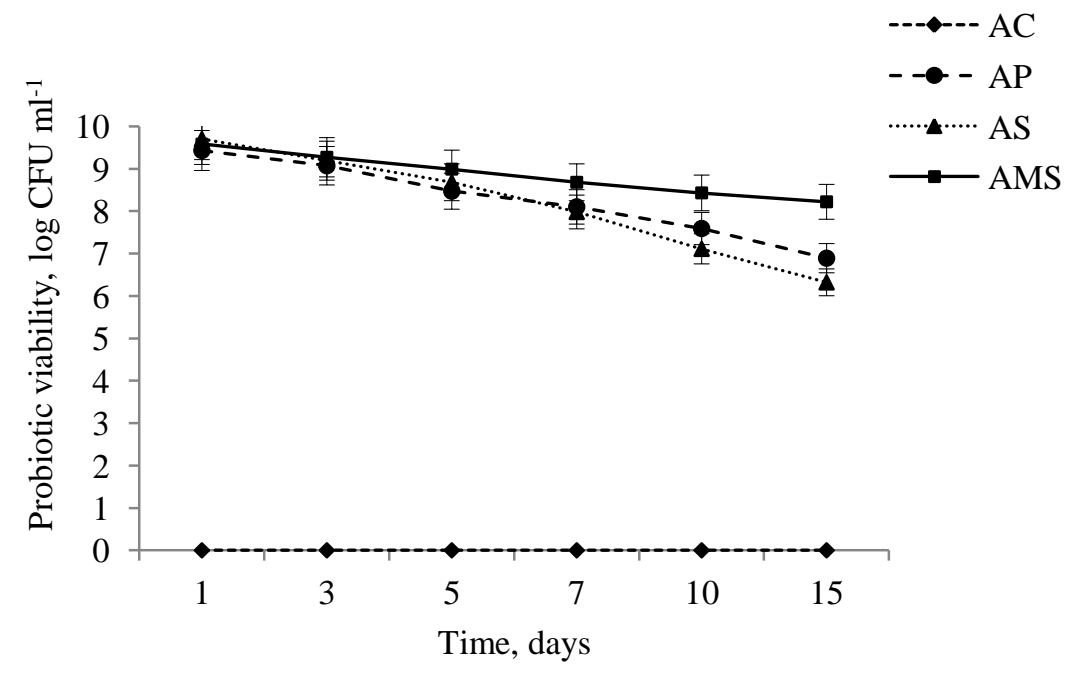

Fig. 1. Probiotic viability in ayran samples during 15 days storage at $4{ }^{\circ} \mathrm{C}$.

AC - conventional ayran; AP - L. casei 01 enriched ayran; AS - L. casei 01 and Synergy 1 enriched ayran: AMS - ayran enriched with encapsulated L. casei 01 and Synergy 1. 
Encapsulated L. casei 01 showed higher viability compared to free probiotic cells during the storage period of ayran samples. At the end of the storage, the viability of non-encapsulated cells was reduced for 2.54 and $3.38 \operatorname{logs}$ in ayran containing L. casei 01 alone and in ayran containing $L$. casei 01 and oligofructose-enriched inulin, respectively, while viability loss of encapsulated cells was 1.21 $\log$ cycles. The better survival rate of encapsulated L. casei 01 is probably enabled by double encapsulation due to the chitosan coating making the structure of highly porous alginate particles denser. Improved stability of chitosan-coated alginate particles provided better probiotic viability during incorporation and storage in foods [30, 31].

An increase of one log cycle in the viability of L. acidophilus 547 encapsulated in chitosancoated alginate microparticles by extrusion when compared to the free yogurt cells after 4 weeks of refrigerated storage has been reported [32]. Viability of L. plantarum BLO11 encapsulated in alginate particles coated with chitosan using an emulsion method showed a decline of only $0.55 \mathrm{log}$ after 38 days of cold storage of yogurt [30]. Some recent studies [31, 33, 34] also revealed that microencapsulation improved the viability of probiotic cells added to yogurts when compared to the free cells, investigating different probiotic strains, microencapsulation techniques and encapsulating materials. Alginate beads coated with chitosan containing $L$. acidophilus, $L$. reuteri or their mixture promoted the lactobacilli stability and thus viability in yogurt [31].

In our study, a surprising result was that non-encapsulated $L$. casei 01 survived better upon storage of ayran samples when it was added alone compared to non-encapsulated L. casei 01 combined with oligofructose-enriched inulin. The behavior of the probiotic may be influenced by the source of the prebiotic and/or food matrix. In addition, the probiotic strain itself may be insufficient in enzymes that efficiently hydrolyze the prebiotic into low-molecular sugars serving as substrates for the cells. Subsequently, the prebiotic could not be used efficiently by the probiotic cells incorporated into the matrix, while at the same time it may increase the osmotic pressure in the medium and negatively affect the probiotic survival.

\subsection{Production of organic acids in functional ayran samples}

Lactic acid bacteria, such as the strains of $L$. delbrueckii subsp. bulgaricus and Streptoccocus thermophilus, which are often used in yogurt man- ufacture, produce lactic acid from lactose when added to milk. These strains are not of human origin, could be destroyed in the gut and are not able to colonize the human intestine. Lactic acid bacteria known to possess probiotic properties can be incorporated into food products along with yogurt cultures in such a way as to increase the production of lactic acid. Hence, changes in production of lactic acid and SCFAs (acetic, propionic and butyric acid), which can be also produced into the medium due to the saccharolytic activity of probiotic cultures, were determined in probiotic and synbiotic ayran samples and compared to the control sample.

Lactic acid and SCFAs are positively correlated to certain nutritional and functional properties of the products. The typical but likable taste of fermented dairy products is a consequence of the presence of lactic acid, which is known to enhance the sensory and nutritional profile of the products. SCFAs, mainly acetate, propionate, butyrate and lactate as important intermediates in the formation of SCFAs have been found to alter gut integrity and to possess anti-inflammatory, antimicrobial and anticarcinogenic effects, thus playing significant roles in the maintenance of gut and immune homeostasis [35].

Higher lactic and acetic acid concentrations were found in ayran enriched with $L$. casei 01 and oligofructose-enriched inulin compared to control ayran. However, the insignificant difference in acidity among samples examined may be considered as a technological advantage, since a high concentration of acid compounds is related to production of off-flavors and negative effects on consumer acceptance [7]. Lactic acid production increased to $69.93 \mathrm{mmol}^{-1}$ at day 5 and $69.05 \mathrm{mmol}$ $1^{-1}$ at day 7 of the storage in samples containing non-encapsulated synbiotic and probiotic, respectively, while the highest concentration (81.83 mmol $\mathrm{l}^{-1}$ ) was found in the sample containing synbiotic microparticles (Fig. 2a). The concentration of acetic acid (Fig. 2b) followed the increasing trend of lactic acid production, with the highest value of $79.93 \mathrm{mmol} \mathrm{l}^{-1}$ measured in the sample containing microparticles at day 7 of the storage. These results confirmed the protective role of encapsulation in the maintenance of viability and metabolic activity of $L$. casei 01 added to ayran. Propionic acid was measured at low concentrations and remained almost constant for each sample during the storage, rather than being absent in conventional ayran (Fig. 2c). Herein, butyric acid production was not detected. Compared to the sample containing non-encapsulated probiotic, the sample 
containing non-encapsulated synbiotic showed lower lactic and acetic acid production. This is consistent with the finding of lower cell viability in the sample containing non-encapsulated synbiotic. Our results are in contradiction to those reported by Donkor et al. [36] who noticed that production of lactic and acetic acid was significantly higher when inulin was added to the yogurt samples containing L. acidophilus L10 or L. paracasei L26.

a)

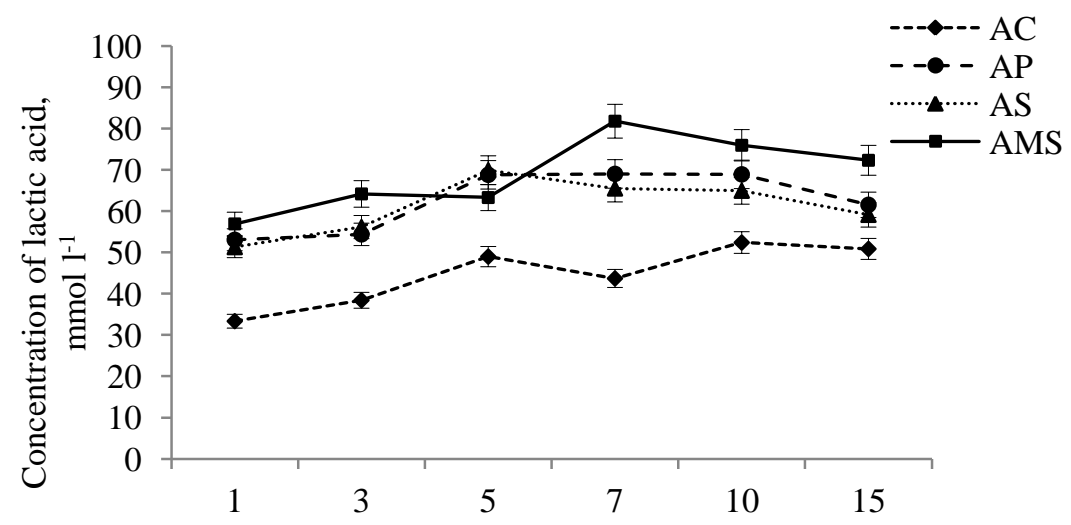

Time, days

b)

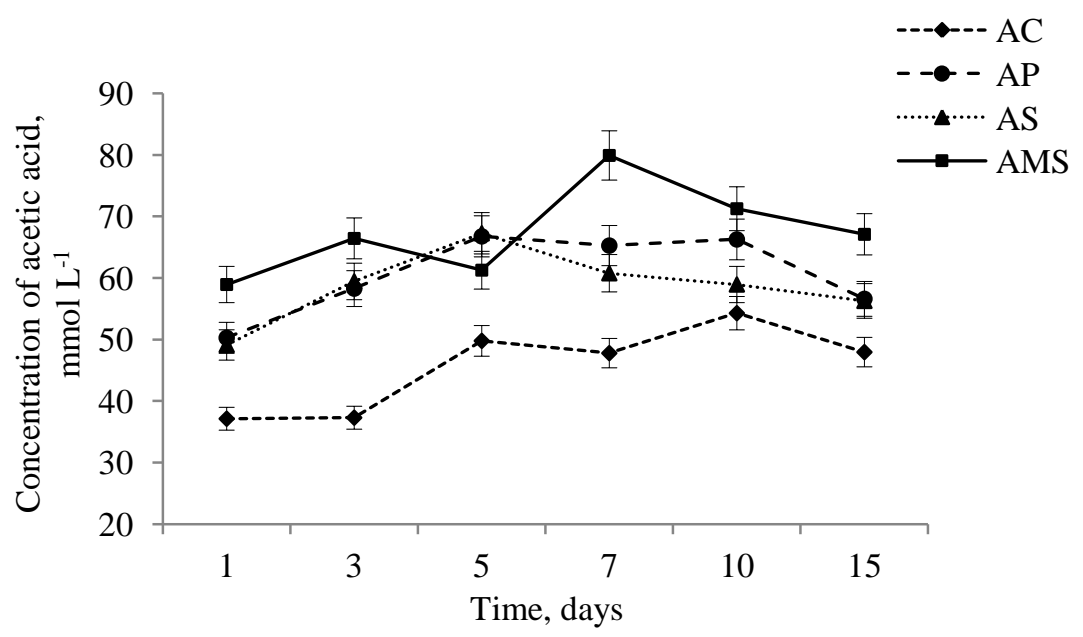

c)

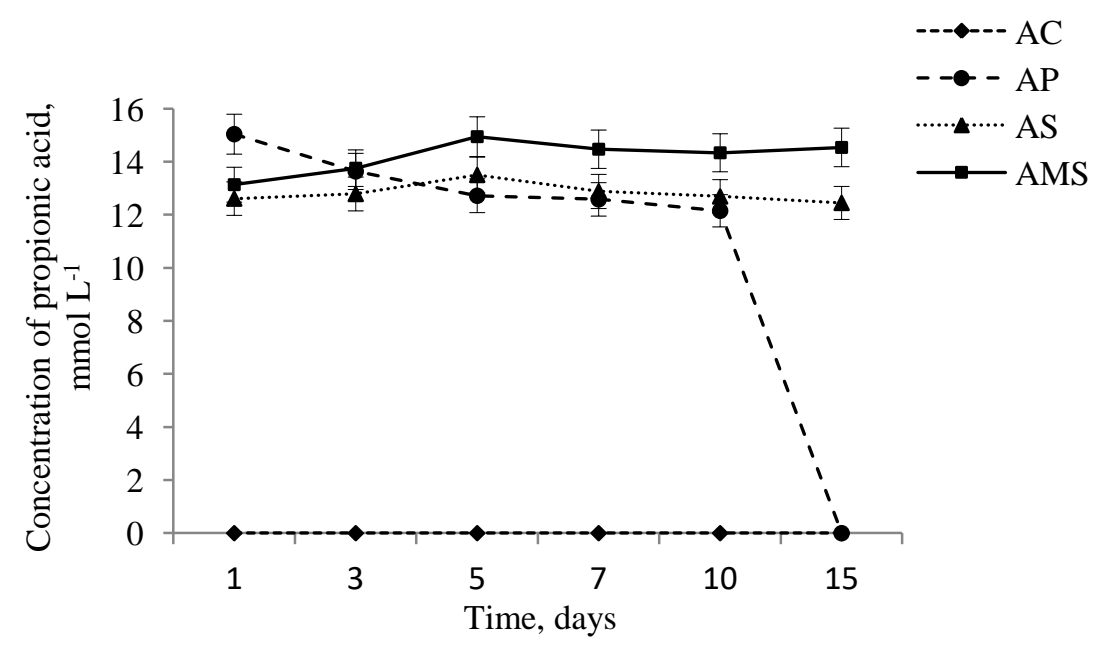

Fig. 2. Concentration of lactic acid (a), acetic acid (b) and propionic acid (c) in ayran samples during 15 days storage at $4{ }^{\circ} \mathrm{C}$. AC - conventional ayran; AP - L. casei 01 enriched ayran; AS - L. casei 01 and Synergy 1 enriched ayran:

AMS - ayran enriched with encapsulated L. casei 01 and Synergy 1. 
The prebiotic oligofructose-enriched inulin did not positively influence the in-situ production of lactic, acetic and propionic acids in our study. However, inulin is resistant to digestion in the upper GIT and reaches the colon intact where it can be fermented by resident saccharolytic microbiota, followed by the production of SCFAs. Higher production of lactic and acetic acid in ayran with microencapsulated synbiotic compared to samples containing non-encapsulated probiotic or synbiotic over all storage periods confirmed the protective role of encapsulation in the maintenance of viability and metabolic activity of $L$. casei 01 in ayran. The relatively low propionic acid concentrations measured in functional ayran samples instead of its absence in control ayran are also inconsistent with the report by Donkor et al. [36], who found that mixed yogurt cultures produced more propionic acid in the absence of probiotics. The opposite observation may due to the metabolic specificity of the probiotic strain, or to possible interactions between the probiotic and yogurt cultures. Donkor et al. [36] determined low concentrations of butyric acid in probiotic/synbiotic yogurts containing $L$. acidophilus L10 or L. paracasei L26 and inulin or Hi-maize, while in probiotic/synbiotic ayran containing L. casei 01 and Synergy 1, no production of butyric acid was observed. However, the production of butyrate is possible after consumption, after the probiotic or synbiotic has reached the large bowel.

\section{CONCLUSIONS}

In this study, new probiotic/synbiotic dairy drinks containing therapeutic levels of viable and active cells of Lactobacillus casei 01 were developed. Ayran samples enriched with synbiotic microparticles have the main advantage in terms of probiotic survival and increased production of lactic, acetic and propionic acid. This newly developed product gained functional properties, while retaining the quality of conventional ayran and may be offered to consumers as a part of a healthy diet. Future perspectives include consumer acceptance studies as an essential part of the design process of each food product, while the impact of such a product enriched with compounds beneficial for health on overall consumer perception should also be tested.

Acknowledgments. This research was financially supported by the Ministry of Education and Science of the Republic of Macedonia (Project No. 13-3583/1). The authors would like to express gratitude to Orafti Beneo Group and to IMCD (UK) for the donation of Orafti ${ }^{\circledR}$ Synergy 1 (L. Maréchal, Tienen, Belgium), and sodium alginate (Protanal 10/60 LS, FMC BioPolymer, USA), respectively.

\section{REFERENCES}

[1] C. Ceapa, H. Wopereis, L. Rezaïki, M. Kleerebezem, J. Knol, R. Oozeer, Influence of fermented milk products, prebiotics and probiotics on microbiota composition and health, Best Pract. Res. Clin. Gastroenterol., 27(1), 139155 (2013). DOI: 10.1016/j.bpg.2013.04.004

[2] M. L. Marco, D. Heeney, S. Binda, C. J. Cifelli, P. D. Cotter, B. Foligné, M. Gänzle, R. kort, G. Pasin, A. Pihlanto, E. J. Smid, R. Hutkins, Health benefits of fermented foods: microbiota and beyond, Curr. Opin. Biotechnol., 44, 94-102 (2017). DOI: 10.1016/j.copbio.2016.11.010

[3] C. F. Balthazar, H. L. A. Silva, E. A. Esmerino, R. S. Rocha, J. Moraes, M. A. V. Carmo, L. Azevedo, I. Camps, Y. K. D. Abud, C. Sant'Anna, R. M. Franco, M. Q. Freitas, M. C. Silva, R. S. L. Raices, G. B. Escher, D. Granato, C. S. Ranadheera, F. Nazarro, A. G. Cruz, The addition of inulin and Lactobacillus casei 01 in sheep milk ice cream, Food Chem., 246, 464-472 (2018). DOI: $10.1016 /$ j.foodchem.2017.12002

[4] T. Petreska Ivanovska, K. Mladenovska, Z. Zhivikj, M. Jurhar Pavlova, I. Gjurovski, T. Ristoski, L. Petrushevska-Tozi, Synbiotic loaded chitosan-Caalginate microparticles reduces inflammation in the TNBS model of rat colitis, Int. J. Pharm., 527, 126-134 (2017). DOI: 10.1016/j.ijpharm2017.05.049

[5] E. Vaghef-Mehrabany, B. Alipour, A. Homayouni-Rad, S. K. Sharif, M. Asghari-Jafarabadi, S. Zavvari, Probiotic supplementation improves inflammatory status in patients with rheumatoid arthritis, Nutrition, 30, 430 435 (2014). DOI:10.1016/j.nut.2013.09.007

[6] S. Nualkaekul, D. Lenton, M. T. Cook, V. V. Khutoryanskiy, D. Charalampopoulos, Chitosan coated alginate beads for the survival of microencapsulated Lactobacillus plantarum in pomegranate juice, Carbohydr. Polym., 90(3), 1281-1287 (2012). DOI: https://doi.org/10.1016/j.carbpol.2012.06.073

[7] A. L. D. Batista, R. Silva, L. P. Cappato, C. N. Almada, R. K. A. Garcia, M. C. Silva, R. S. L. Raices, D. B. Arellano, A. S. Sant'Anna, C. A. Conte Junior, Quality parameters of probiotic yogurt added to glucose oxidase compared to commercial products through microbiological, physico-chemical and metabolic activity analyses, Food Res. Int., 77, 627-635 (2015).

DOI: 10.1016/j.foodres.2015.08.017

[8] G. Mitropoulou, V. Nedovic, A. Goyal, Y. Kourkoutas, Immobilization technologies in probiotic food production, J. Nutr. Metab., 2013, 1-15 (2013). DOI: http://dx.doi.org/10.1155/2013/716861

[9] M. T. Cook, G. Tzortzis, D. Charalampopoulos, V. V. Khutoryanskiy, Microencapsulation of probiotics for gastrointestinal delivery, J. Control. Release, 162, 56-67 (2012). DOI: 10.1016/j.jconrel.2012.06.003.

[10] T. Petrović, V. Nedović, S. Dimitrijević-Branković, B. Bugarski, C. Lacroix, Protection of probiotic microorganisms by microencapsulation, Chem. Ind. Chem. Eng. Q., 13(3), 169-174 (2007).

DOI: 10.2298/CICEQ0703169P.

[11] Turkish Food Codex: Fermented Milk Products, Regulation No: 2009/25, Ministry of Food, Agriculture and Livestock, Turkey, Ankara (2009). 
[12] F. Altay, F. Karbancioglu-Güler, C. Daskaya-Dikmen, D. Heperkan, A review on traditional Turkish fermented non-alcoholic beverages: microbiota, fermentation process and quality characteristics, Int. J. Food Microbiol., 167(1), 44-56 (2013).

DOI: $10.1016 / \mathrm{j}$. .ijfoodmicro.2013.06.016.

[13] R. P. S. Oliveira, A. C. R. Florence, R. C. Silva, P. Perego, A. Converti, A. L. Gioeilli, M. N. Oliveira, Effect of different prebiotics on the fermentation kinetics, probiotic survival and fatty acids profiles in non-fat synbiotic fermented milk, Int. J. Food Microbiol., 128(3), 467-472 (2009). DOI: 10.1016/j.ijfoodmicro.2008.10.012.

[14] R. P. De Souza Oliveira, P. Perego, M. N. De Oliveira, A. Converti, Effect of inulin as prebiotic and synbiotic interactions between probiotics to improve fermented milk firmness, J. Food Eng., 107(1), 36-40 (2011). DOI: 10.1016/j.jfoodeng.2011.06.005.

[15] A. Köksoy, M. Kiliç, Effects of water and salt level on rheological properties of ayran, a Turkish yoghurt drink, Int. Dairy J., 13, 835-839 (2003).

DOI: dx.doi.org/10.1016/S0958-6946(03)00103-1.

[16] D. Granato, G. F. Branco, A. G. Cruz, J. A. F. Faria, N. P. Shah, Probiotic dairy products as functional foods, Compr. Rev. Food Sci. Food Safety, 9, 455-470 (2010). DOI: 10.1111/j.1541-4337.2010.00120.x.

[17] T. Petreska Ivanovska, L. Petrushevska-Tozi, A. Grozdanov, R. Petkovska, J. Hadjieva, E. Popovski, T. Stafilov, K. Mladenovska, From optimization of synbiotic microparticles prepared by spray-drying to development of new functional carrot juice, Chem. Ind. Chem. Eng. Q., 20(4), 549-564 (2014).

DOI: $10.2298 / C I C E Q 130218036$ P.

[18] AOAC, Official Methods of Analysis Chemists, $15^{\text {th }}$ ed. Association of Official Analytical Chemists - AOAC, Virginia, Arlington, USA (1990).

[19] D. H. Kleyn, J. M. Lynch, D. M. Barbano, M. J. Bloom, M. W. Mitchell, Determination of fat in raw and processed milks by the Gerber method: collaborative study, J. AOAC Int., 84(5), 1499-1508 (2001).

[20] M. M. Bradford, A rapid and sensitive method for the quantitation of protein using the principle of protein-dye binding, Anal. Biochem., 72(1-2), 248-254 (1976). DOI: 10.1016/0003-2697(76)90527-3.

[21] D. Pan, Y. Guo, Optimization of sour milk fermentation for the production of ACE-inhibitory peptides and purification of a novel peptide from the whey protein hydrolisate, Int. Dairy J., 20, 472-479 (2010). DOI: $10.1016 /$ j.idairyj.2010.01.007.

[22] B. O. Al-Abdulkarim, M. S. Osman, M. A. I. El-Nadeef, Determination of chemical composition, and storage on dried fermented goat milk product (Oggtt), J. Saudi Soc. Agric. Sci., 12, 161-166 (2013). DOI: https://doi.org/10.1016/j.jssas.2012.11.003.

[23] A. Galat, J. Dufresne, J. Combrisson, A. Thépaut, L. Boumghar-Bourtchai, M. Boyer, C. Fourmestraux, Novel method based on chromogenic media for discrimination and selective enumeration of lactic acid bacteria in fermented milk products, Food Microbiol., 55, 86-94 (2016). DOI: https://doi.org/10.1016/j.fm.2015.11.005.

[24] T. Y. Sheu, R. T. Marshall, H. Heymann, Improving survival of culture bacteria in frozen desserts by microentrapment, J. Dairy Sci. 76(7), 1902-1907 (1993). DOI: https://doi.org/10.3168/jds.S00220302(93)77523-2.

[25] Y. C. Wang, R. C. Yu, H. Y. Yang, C. C. Chou, Sugar and acid contents in soymilk fermented with lactic acid bacteria alone or simultaneously with bifidobacteria, Food Microbiol. 20(3), 333-338 (2003). DOI: 10.1016/S0740-0020(02)00125-9.

[26] J. C. Zhao, Z. A. Guo, J. H. Chang, W. J. Wang, Study on reversed-phase high performance liquid chromatography separation condition and determination method of organic acids, Se Pu 19(3), 260-263 (2001).

[27] F. P. De Castro, T. M. Cunha, P. J. Ogliari, R. F. Teófilo, M. M. C. Ferreira, E. S. Prudêncio, Influence of different content of cheese whey and oligofructose on the properties of fermented lactic beverages: Study using response surface methodology, LWT-Food Sci. Technol., 42, 993-997 (2009). DOI:10.1016/j.1wt.2008.12.010.

[28] F. Miremadi, F. Sherkat, L. Stojanovska, Hypocholaesterolemic effect and anti-hypertensive properties of probiotics and prebiotics: a review. $J$. Funct. Foods, 25, 497-510 (2016). DOI: 10.1016/j.jff.2016.06.016.

[29] C. Koçak, Y. K. Avşar, B. Tamuçay, A comparative study on the production methods of ayran, Grda 31(4), 225-231 (2006).

[30] G. Z. Brinques, M. A. Z. Ayub, Effect of microencapsulation on survival of Lactobacillus plantarum in simulated gastrointestinal conditions, refrigeration, and yogurt, J. Food Eng. 103(2), 123-128 (2011). DOI: https://doi.org/10.1016/j.jfoodeng.2010.10.006.

[31] A. García-Ceja, E. Mani-López, E. Palou, A. LópezMalo, Viability during refrigerated storage in selected food products and during simulated gastrointestinal conditions of individual and combined lactobacilli encapsulated in alginate or alginate-chitosan, LWT-Food Sci. Technol., 63(1), 482-489 (2015). DOI: http://dx.doi.org/10.1016\%2Fj.lwt.2015.03.071.

[32] W. Krasaekoopt, B. Bhandari, H. C. Deeth, Survival of probiotics encapsulated in chitosan-coated alginate beads in yoghurt from UHT- and conventionally treated milk during storage, LWT-Food Sci. Technol. 39, 177183 (2006). DOI: 10.1016/j.lwt.2004.12.006.

[33] P. Chaikham, Stability of probiotics encapsulated with Thai herbal extracts in fruit juices and yoghurt during refrigerated storage, Food Biosci. 12, 61-66 (2015). DOI: 10.1016/j.fbio.2015.07.006.

[34] M. C. E. Ribeiro, K. S. Chaves, C. Gebara, F. N. S. Infante, C. R. F. Grosso, M. L. Gigante, Effect of microencapsulation of Lactobacillus acidophilus LA-5 on physicochemical, sensory and microbiological characteristics of stirred probiotic yoghurt, Food Res. Int., 66, 424-431 (2014). DOI: 10.1016/j.foodres.2014.10.019.

[35] J. Tan, C. McKenzie, M. Potamitis, A. N. Thornburn, C. R. Mackay, L. Macia, The role of short-chain fatty acids in health and disease, Adv. Immunol., 121, 91-119 (2014). DOI: 10.1016/B978-0-12-800100-4.00003-9.

[36] O. Donkor, S. Nilmini, P. Stolic, T. Vasiljevic, N. P. Shah, Survival and activity of selected probiotic organisms in set-type yoghurt during cold storage, Int. Dairy J., 17(6), 657-665 (2007). 
DOI: https://doi.org/10.1016/j.idairyj.2006.08.006. 